Lister, A. J. (1956). J. gen. Microbiol. 14, 478-484,

\title{
The Kinetics of Urease Activity in Corynebacterium renale
}

\author{
BY A. J. LISTER \\ Department of Biochemistry, University of Cambridge
}

SUMMARY: The urease activity of Corynebacterium renale has been studied in washed suspensions and in cell-free extracts of the micro-organism. The urease is constitutive, and whole organisms have a urease activity of 17,000-22,000 $\mu \mathrm{g} . \mathrm{NH}_{3} /$

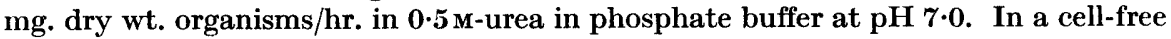
extract the enzyme is optimally active at $\mathrm{pH} 7.5$, has a Michaelis constant of $0.030 \mathrm{M}$, and a temperature velocity constant of $7800 \mathrm{cal}$; t the activity is inhibited by atmospheric oxygen and by thiourea, but not by sixteen other analogues of urea tested.

Corynebacterium renale is the causative organism of a specific bovine pyelonephritis. Observations made on natural infections in cattle and on experimental infections in mice and rabbits have established that there is a specific localization of the micro-organism in the medulla of the kidney (Lovell, 1946; Lovell \& Cotchin, 1946; Feenstra, Thorp \& Gray, 1949). The work presented in this paper is part of an attempt to establish a relationship between the biochemical characteristics of the micro-organism and the specificity of the infection which it produces.

Following reports that Corynebacterium renale produced ammonia when grown in urine, Lovell \& Harvey (1950), using suspensions of acetone powders of the micro-organism, investigated the production of ammonia from amino acids and several other nitrogenous substances found in urine, and showed that the rate of production of ammonia from urea was very much greater than that from any other substrate tested. Whole organisms of $C$. renale have, in fact, a very high urease activity with a $q_{\mathrm{NH}_{3}}$ value (expressed as $\mu \mathrm{g}$. of ammonia produced/mg. dry wt. organisms/hr.) of about 20,000, which is higher than the catalase activity of some micro-organisms. A study has been made of the kinetics of the activity of this urease as a preliminary to the investigation of the role of the enzyme in the aetiology of pyelonephritis.

\section{METHODS}

Organism and growth medium. The organism used was Corynebacterium renale strain 4, kindly supplied by Prof. R. Lovell of the Royal Veterinary College. It was grown in Roux bottles (150 ml. medium/bottle) in a liquid medium of the following composition $(\%, w / v)$ : peptone (Oxoid) 1; Lab Lemco 1; Marmite $0 \cdot 1 ; \mathrm{NaCl} 0 \cdot 5$; Tween $800 \cdot 1$.

Suspensions of organisms and cell-free extracts. Organisms for the estimation of urease activity were grown for $24 \mathrm{hr}$. at $37^{\circ}$, harvested by centrifugation, washed twice in $0.1 \%(\mathrm{w} / \mathrm{v}) \mathrm{Na}_{2} \mathrm{~S}$ adjusted to $\mathrm{pH} 7$ with dilute acetic acid 
( $\mathrm{Na}_{2} \mathrm{~S}$ solution), and suspended in $\mathrm{Na}_{2} \mathrm{~S}$ solution at a density of approximately $0.5 \mathrm{mg}$. dry wt./ml. To obtain a cell-free extract, a suspension of organisms of density c. $10 \mathrm{mg}$. dry wt./ml., prepared as above, was broken in the Hughes press (Hughes, 1951) and centrifuged at $10,000 \mathrm{~g}$ for $30 \mathrm{~min}$. to remove cell debris. The supernatant fluid was diluted with 500 vol. of $\mathrm{Na}_{2} \mathrm{~S}$ solution before use.

Estimation of urease activity. Urease activity was measured in two ways. In the first method, the procedure of Krebs \& Henseleit (1932) was modified by gassing the manometers with $\mathrm{H}_{2}$ or $\mathrm{N}_{2}$. In the second method (Sumner \& Myrbäck, 1951), $1 \mathrm{ml}$. of M-urea in phosphate buffer ( $\mathrm{pH} \mathrm{7.0)}$ was incubated at $37^{\circ}$ with $1 \mathrm{ml}$. of a urease preparation. After a suitable period of time, usually about 20 min., when not more than $3 \%$ of the urea had been broken down, $1 \mathrm{ml} . \mathrm{N}-\mathrm{HCl}$ was added to stop the reaction. A sample $(2 \mathrm{ml}$.) of the reaction mixture was brought to a final $\mathrm{pH}$ value of about $9 \cdot 2$ with borate buffer, and distilled in the Parnas apparatus (Parnas \& Heller, 1924). The ammonia collected was estimated colorimetrically with Nessler's solution, using the Spekker absorptiometer with Ilford 601 filters. For blank values the above procedure was followed, except that $1 \mathrm{ml}$. $\mathrm{N}-\mathrm{HCl}$ was added before addition of the enzyme. For each determination of urease activity, enzyme was added to ten identical tubes at 20 sec. intervals, and the average of the results obtained was corrected by the subtraction of a blank value determined in duplicate.

\section{RESULTS}

\section{The estimation of urease activity}

The urease activity of Corynebacterium renale proved very difficult to estimate with accuracy owing to its rapid inactivation by atmospheric oxygen. When a washed suspension or a cell-free extract was shaken in a manometer flask gassed with air, a rapid and progressive loss of activity resulted. There was no progressive loss of activity when the manometers were gassed with $\mathrm{H}_{2}$ or $\mathrm{N}_{2}$, but the standard error of a set of ten identical estimations was as high as $10 \%$ of the mean value, and this error was not decreased by introducing a small piece of yellow phosphorus into the centre well of the manometer vessels, by suspending the organisms in sodium mercaptoacetate (thioglycollate) or cysteine, or by washing the manometer vessels in versene to avoid inactivation by heavy metals. However, to minimize aerobic inactivation, cells were routinely washed and suspended in $\mathrm{Na}_{2} \mathrm{~S}$ solution.

Treatment of organisms with the detergent cetyltrimethylammonium bromide (CTAB), at a concentration of $30 \mu \mathrm{g} . / \mathrm{mg}$. dry wt. organisms, increased the urease activity threefold. Under these conditions, the standard error of ten determinations fell to $3 \%$. It is suggested that a considerable part of the standard error of $10 \%$ may have been due to the lysis of different quantities of organisms in each manometer vessel. For this reason all the kinetic determinations reported in this paper were performed on cell-free extracts of Corynebacterium renale. The second method of estimation (above) was used because it is inconvenient to carry out a large number of simultaneous 
determinations in manometers. A reliable estimate of urease activity was obtained by taking the average of ten identical estimations in each case. That this method provided a satisfactory and accurate estimate of urease activity is illustrated in Fig. 1, which shows the rate of production of ammonia from $0.5 \mathrm{M}$-urea at $\mathrm{pH} 7.0$ by the cell-free extract. Despite the scatter of the results (shown by the vertical bars above and below each point), the mean values approximate well to the best straight line drawn through the origin.

\section{The urease activity of whole organisms and of cell-free extracts}

The urease activity of Corynebacterium renale, assayed in $0.5 \mathrm{M}$-urea at $\mathrm{pH} 7 \cdot 0$, had a $q_{\mathrm{NH}_{\mathrm{s}}}$ value $\left(\mu \mathrm{g}\right.$. $\mathrm{NH}_{3}$ produced/mg. dry wt. organisms/hr.) varying between $\mathbf{1 7 , 0 0 0}$ and $\mathbf{2 2 , 0 0 0}$. The enzyme is constitutive: it is possessed by organisms which have been grown in media containing no urea, and furthermore, the activity was not increased by growth in media containing urea, or by varying the $\mathrm{pH}$ value of the growth medium between 6.5 (the $\mathrm{pH}$ value below which the micro-organism does not grow) and 9.0. When a washed suspension of organisms was incubated with urea for a time sufficient for the reaction to reach completion, 2 molecules of ammonia were produced from 1 molecule of urea.

The enzyme was present in a soluble form in a cell-free extract, and centrifugation in the Spinco ultracentrifuge at $150,000 \mathrm{~g}$ for $45 \mathrm{~min}$. to remove small particles resulted in no loss of activity. The extract was stable in $\mathrm{Na}_{2} \mathrm{~S}$ solution for at least $3 \mathrm{hr}$. at $4^{\circ}$, but was slowly inactivated after longer periods at this temperature; it was rapidly inactivated by freezing to $-15^{\circ}$ and by dialysis. In this latter respect it resembles the urease of Bacillus pasteurii described by Larson \& Kallio (1954). An attempt was made to purify the enzyme by the procedures described by these authors, and at each fractionation material active as urease was separated from an inactive residue. However, even in the presence of $\mathrm{Na}_{2} \mathrm{~S}$ solution, each step was accompanied by a marked decrease in total urease activity, and after removing $97 \cdot 3 \%$ of the initial dry matter by the above procedures the purification was only $2 \cdot 1$-fold, based on the ratio urease activity/dry wt. after dialysis.

\section{The kinetics of the cell-free urease preparation}

Over the range tested the optimum $\mathrm{pH}$ value of the enzyme was $7 \cdot 5$, but there was little diminution in activity over the range of $\mathrm{pH}$ values 6-8 (Fig. 2).

The effect of temperature on urease activity, determined in $0.5 \mathrm{M}$-urea in phosphate buffer $\left(\mathrm{pH} \mathrm{7.0)}\right.$ between $15^{\circ}$ and $45^{\circ}$, is shown in Fig. 3. The values of the temperature coefficient $\left(Q_{10}\right)$ of the enzyme at different temperatures were: $1 \cdot 63\left(15-25^{\circ}\right) ; 1.51\left(25-35^{\circ}\right) ; 1 \cdot 47\left(35-45^{\circ}\right)$. The data of Fig. 3 were used to plot $\log _{10}$ (rate of urease-catalysed reaction) against the reciprocal of the absolute temperature (Fig. 4). When the gradient of the best straight line drawn through these points is multiplied by the factor $-R \ln 10$, where $R$ is the gas constant, the value obtained ( 7800 cal.) is the temperature-velocity constant of the reaction over the range $15-45^{\circ}$. It is possible that the points given 
in Fig. 4 may lie on two non-parallel intersecting straight lines with a critical point at about $27^{\circ}$. Such a critical point has been described by Sizer (1939, 1940, 1941) for the ureases of soybean and of whole Proteus vulgaris, and by Larson \& Kallio (1954) for the purified urease of Bacillus pasteurii. However, Fig. 4 shows that in the case of Corynebacterium renale the change in the gradient of the line, if any, is only small, and because of the errors involved in the estimation no attempt was made to elucidate this point.

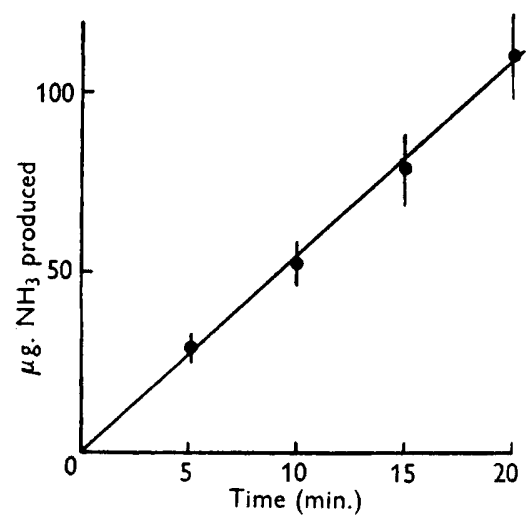

Fig. 1

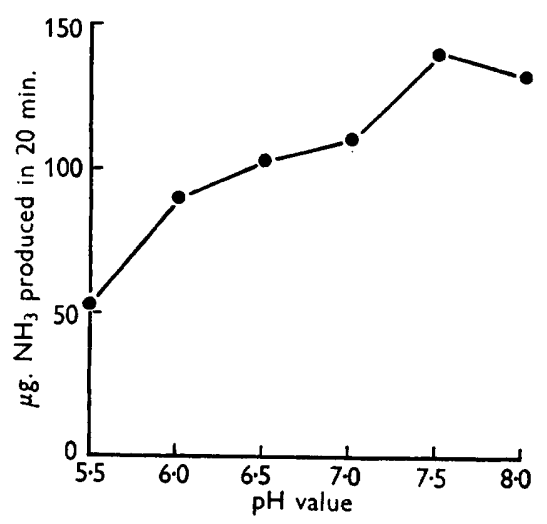

Fig. 2

Fig. 1. The time course of the production of ammonia from $0.5 \mathrm{M}$-urea by a cell-free extract of Corynebacterium renale. The reaction was carried out at $37^{\circ}$ in phosphate buffer $(\mathrm{pH} 7 \cdot 0)$. The vertical bars above and below each point represent the range of 10 identical estimations.

Fig. 2. The effect of $\mathrm{pH}$ value on the urease activity of a cell-free extract of Corynebacterium renale. The data represent the rate of production of ammonia from $0.5 \mathrm{M}$-urea in $0 \cdot 06 \mathrm{M}$-phosphate buffer at $37^{\circ}$.

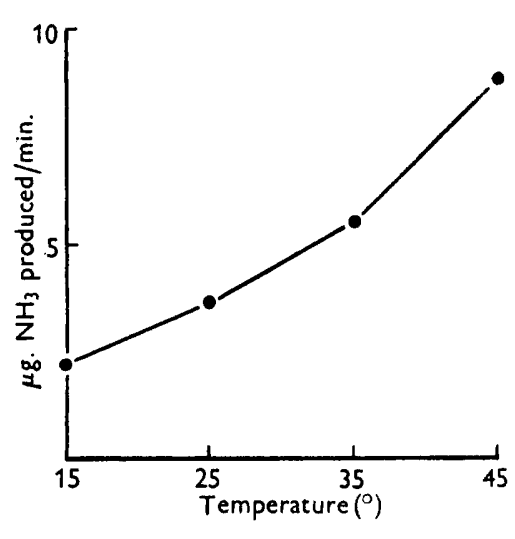

Fig. 3

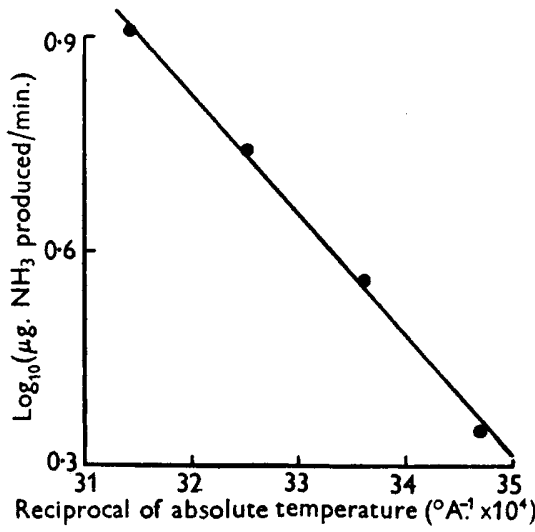

Fig. 4

Fig. 3. The effect of temperature on the urease activity of a cell-free extract of Corynebacterium renale. The data represent the rate of production of ammonia from $0.5 \mathrm{M}$-urea in phosphate buffer ( $\mathrm{pH} 7 \cdot 0)$.

Fig. 4. Calculation of the temperature velocity constant of the urease-catalysed reaction from the data of Fig. 3. 
The effect of substrate concentration on urease activity was determined at $37^{\circ}$ in phosphate buffer $(\mathrm{pH} 7 \cdot 0)$, and the reciprocal of the urease activity was plotted against the reciprocal of the urea concentration (Lineweaver \& Burk, 1934) (Fig. 5). The intercept with the abscissa of the best straight line drawn through the points gives the Michaelis constant of the enzyme. This straight line was calculated statistically, using the results of all the individual determinations, and not only their mean values. In this way it was possible to calculate not only the mean value of the Michaelis constant of the enzyme, which is $0.030 \mathrm{M}$, but also its $95 \%$ confidence limits of $0.026-0.035 \mathrm{M}$. This value may be compared with the values which have been obtained for the ureases of other organisms and which vary between $0 \cdot 10 \mathrm{M}$ for Bacillus pasteurii urease in $0 \cdot 2 \mathrm{M}$ phosphate buffer $\left(\mathrm{pH} 5 \cdot 7\right.$ ) at $25^{\circ}$ (Larson \& Kallio, 1954), and $0.003 \mathrm{M}$ for crystalline jack bean urease in maleic acid buffer ( $\mathrm{pH} \mathrm{7.0)}$ at $25^{\circ}$ (Harmon \& Niemann, 1949).

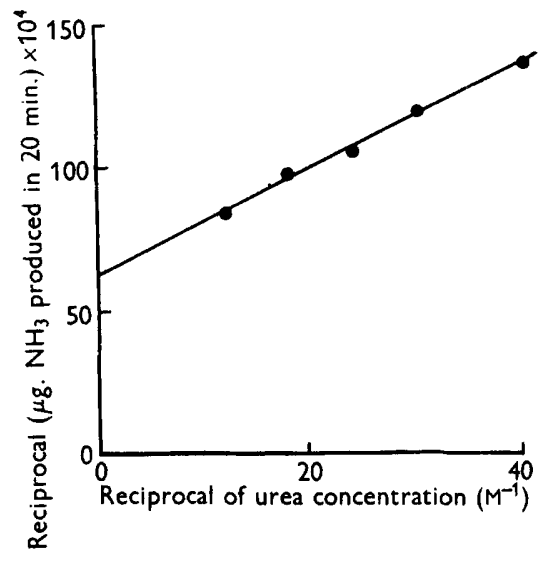

Fig. 5

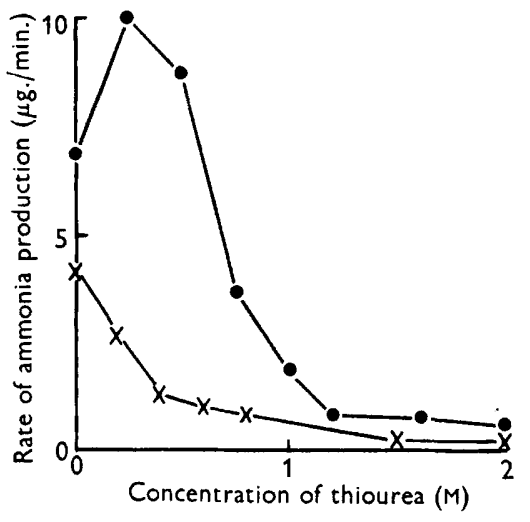

Fig. 6

Fig. 5. The effect of urea concentration on urease activity of a cell-free extract of Corynebacterium renale. Lineweaver \& Burk (1934) plot of reciprocal of rate of ammonia production ( $\mu \mathrm{g}$. $\mathrm{NH}_{3} / 20 \mathrm{~min}$. from $0.5 \mathrm{M}$-urea in phosphate buffer, pH $7 \cdot 0$, at $37^{\circ}$ ) against reciprocal of urea concentration $\left(\mathrm{M}^{-1}\right)$.

Fig. 6. The effect of thiourea concentration on the urease activity of a cell-free extract of Corynebacterium renale. The data represent the rate of production of ammonia from $0.5 \mathrm{M}$-urea in phosphate buffer $(\mathrm{pH} \mathrm{7.0})$ at $37^{\circ}$. $-O$, in the presence of $5 \times 10^{-4} \mathrm{M}^{-}$ cysteine; $x-\times$, in the absence of cysteine.

\section{The effect of urea analogues on urease activity}

An investigation was made of the effect of seventeen analogues of urea upon the urease activity of Corynebacterium renale in order to determine whether any such analogue might be used as an in vivo inhibitor of urease activity. Each compound was added either in saturated solution in the case of the relatively insoluble derivatives (marked with an asterisk below), or at a concentration of $0.1 \mathrm{M}$ for the others, to a cell-free solution of the urease at $\mathrm{pH} 7 \cdot 0$, with and without urea. The urea concentration used in these experi- 
ments was $0.025 \mathrm{M}$ in order to enhance any competitive inhibition by the analogues. Thiourea was the only analogue tested which had an inhibitory action on urease; the following sixteen compounds were not inhibitory: ${ }^{*} N, N^{\prime}$-acetylmethylurea; ${ }^{*} N$-(2-bromo-2-ethylbutyryl)urea (Carbromal); ethylurea; $N, N^{\prime}$-(2-diethylmalonyl)urea (barbitone); methylurea; ${ }^{*} N, N^{\prime}$ dimethyl - $N, N^{\prime}$ - diphenylurea; ${ }^{*} \alpha$ - naphthylurea; *phenylurea; $* N, N^{\prime}$ diphenylurea; $* N, N$-diphenylurea; $*^{*}$-tolylurea; $* m$-tolylurea; $* N, N^{\prime}$-di-otolylurea; ${ }^{*} N, N^{\prime}$-di- $m$-tolylurea; $* N, N^{\prime}$-di- $p$-tolylurea; biuret. Ammonia was not produced from any of the compounds.

The effect of different concentrations of thiourea on the urease activity of a cell-free extract in $0.5 \mathrm{M}$-urea was determined in the presence and absence of $5 \times 10^{-4}$ M-cysteine (Fig. 6). In each case the enzyme was inhibited by the higher concentrations of thiourea, but in the presence of cysteine the urease activity was increased by $0 \cdot 25$ and $0 \cdot 50 \mathrm{M}$-thiourea. Sizer \& Tytell (1941) showed that the activity of crystalline jack bean urease was affected by changes in the oxidation-reduction potential of the test system. Thiourea has a higher oxidation-reduction potential than cysteine; perhaps the activation of Corynebacterium renale urease by thiourea at low concentrations is due to an adjustment of the $\mathrm{rH}$ of the system to a value nearer to that which is optimal, while at higher concentrations this activation is outweighed by the inhibitory action of thiourea.

\section{DISCUSSION}

This study of the urease of Corynebacterium renale has shown that it differs from the other ureases derived from plant and bacterial sources only in minor details. It has been reported that the activity of jack bean urease is markedly dependent on the nature of the inorganic ions present in the test system (Howell \& Sumner, 1934; Harmon \& Niemann, 1949), and while the reasons for this difference in behaviour remain obscure, it is not possible to make a detailed comparison between the various ureases which have been isolated. The chief difference between $C$. renale urease and those ureases which have been described by other workers is that the $C$. renale urease activity/pH curve (Fig. 2) is very flat, whereas a similar curve for plant urease has a sharp peak at the optimum $\mathrm{pH}$ value (Howell $\&$ Sumner, 1934). It may be significant that the activity of the urease of $C$. renale is very high between $\mathrm{pH} 6 \cdot 5$, which is the approximate $\mathrm{pH}$ value of blood and also the $\mathrm{pH}$ value below which this micro-organism cannot grow, and $\mathrm{pH} 8.0$ which is the approximate $\mathrm{pH}$ value of bovine urine. The $C$. renale enzyme is, in fact, very active at any $\mathrm{pH}$ value that this micro-organism is likely to encounter in the bovine kidney. If the $C$. renale urease has an activity of the same order, on a weight for weight basis, as that of crystalline jack bean urease, then this one enzyme would account for $0 \cdot 1-1 \%$ of the total dry weight of $C$. renale. It is possible that the pathogenicity of $C$. renale is due to the local accumulation of high concentrations of ammonia in the kidney, but the kinetic data give no indication of the part played by the urease in the aetiology of pyelonephritis. 
The author wishes to express his gratitude to Professor R. Lovell of the Royal Veterinary College (who suggested this problem) and Dr E. F. Gale, F.R.S., for much helpful advice and encouragement; to Mr R. G. Carpenter of the Department of Human Ecology in the University of Cambridge for assistance with the statistical calculations; and to the Medical Research Council for a Scholarship for Training in Research Methods.

\section{REFERENCES}

Feenstra, E. S., Thorp, Jun., F. \& Gray, M. L. (1949). Pathogenicity of Corynebacterium renale for rabbits. Amer. J. vet. Res. $10,12$.

Harmon, K. M. \& Niemann, C. (1949). The competitive inhibition of the ureasecatalysed hydrolysis of urea by phosphate. J. biol. Chem. 177, 601 .

Howeln, S. F. \& Sumner, J. B. (1934). The specific effects of buffers upon urease activity. J. biol. Chem. 104, 619.

Hughes, D. E. (1951). A press for disrupting bacteria and other micro-organisms. Brit. J. exp. Path. 32, 97.

Krebs, H. A. \& Henseleit, K. (1932). Untersuchungen über die Harnstoffbildung im 'Tierkörper. Hoppe-Seyl. Z. 210, 33.

Larson, A. D. \& Kallio, R. E. (1954). Purification and properties of bacterial urease. J. Bact. 68, 67 .

Lineweaver, H. \& Burk, D. (1934). The determination of enzyme dissociation constants. J. Amer. chem. Soc. 56, 658.

Loveli, R. (1946). Studies on Corynebacterium renale. 1. A systematic study of a number of strains. J. comp. Path. 56, 196.

Lovelu, R. \& Cotchin, E. (1946). Studies on Corynebacterium renale. 2. The experimental pathogenicity for mice. J. comp. Path. 56, 205.

Lovell, R. \& Harvey, D. G. (1950). A preliminary study of ammonia production by Corynebacterium renale and some other pathogenic bacteria. J. gen. Microbiol. 4, 493 .

Parnas, J. K. \& Heller, J. (1924). Über den Ammoniakgehalt und über die Ammoniakbildung im Blute. Biochem. Z. 152, 1.

Sizer, I. W. (1939). Temperature activation of the urea-urease system using crude and crystalline urease. J. gen. Physiol. 22, 719 .

Sizer, I. W. (1940). The activation energy of urea hydrolysis catalysed by soybean urease. J. biol. Chem. 132, 209.

Sizer, I. W. (1941). Temperature activation of the urea-urease system using urease of Proteus vulgaris. J. Bact. 41, 511.

Sizer, I. W. \& Tytell, A. A. (1941). The activity of crystalline urease as a function of oxidation-reduction potential. J. biol. Chem. 138, 631.

Sumner, J. B. \& MYrbäck, K. (1951). The Enzymes, vol. 1, pt. 2, p. 889. New York: Academic Press Inc. 